\title{
Effectiveness of the Use of Graphic Organizers and Summaries: A Case Study of Adult EFL Students in a Reading Comprehension Course
}

\author{
Daniela BarRantes TorRes \\ Escuela de Lenguas Modernas \\ Universidad de Costa Rica
}

\begin{abstract}
This study is aimed at providing an answer to the question of how the use of partially-completed graphic organizers and summaries can help students get the gist of different texts. The review of the literature makes reference to the benefits of using graphic organizers and summaries to understand the gist of texts. The information gathered supports the premise that graphic organizers should be used as a while-reading strategy while summaries should be used as a post-reading strategy. Summaries are helpful for readers to show real comprehension of texts as well as for teachers to evaluate their students' understanding of the main ideas of different readings. Additionally, the results show that students value the advantages of using both strategies to read texts in English.
\end{abstract}

Key words: graphic organizers, summaries, main ideas, reading strategies, texts, reading comprehension

\begin{abstract}
Resumen
Este estudio pretende responder la pregunta de cómo el uso de diagramas parcialmente completos así como también los resúmenes pueden ayudar a los estudiantes a obtener la idea principal de diferentes textos. El marco teórico hace referencia a los beneficios de usar diagramas y resúmenes para comprender la idea principal de los textos. La información recopilada apoya la premisa de que los diagramas deben ser usados como una estrategia de lectura mientras los resúmenes deben ser usados como una estrategia de post-lectura. Los resúmenes son útiles para los lectores que muestran una comprensión real de los textos así como también para que los docentes evalúen el entendimiento de las ideas principales de diferentes lecturas por parte de sus estudiantes. Además, los resultados muestran que los estudiantes valoran las ventajas de usar ambas estrategias para leer textos en inglés.
\end{abstract}

Palabras claves: diagramas, resúmenes, ideas principales, estrategias de lectura, textos, comprensión de lectura 
his research was carried out with a group taking the course called "Strategies of Reading Comprehension in English II" (LM-1032) from the Section of English for Other Majors (SIPOC) at the School of Modern Languages from the University of Costa Rica, specifically on the Rodrigo Facio Campus. In LM-1032, advanced reading comprehension strategies are taught to students who study other majors rather than English. They have to analyze rhetorical patterns and discourse, which means that they should be more critical when analyzing texts; they are actually expected to interact with the text in order to create meaning from print. Identifying main ideas of different types of texts is a topic that has to be constantly reviewed and reinforced in class because this is a way to raise awareness about its relevance when carrying out other exercises that involve critical thinking. However, a lot of learners struggle to accomplish this task. Some of the major reasons of this problem may be the lack of practice or even of solid bases in the strategies that they need to know in order to register this course and the lack of proficiency in the foreign language. Indeed, the course has to be taught in Spanish to ease the students' understanding of the explanations provided by the instructor.

Langdon and Chou (2001) stress that identifying main ideas does not constitute a simple task for learners of different ages (p. 114). In order to tackle this problem, instructors should teach different strategies to help students improve their understanding of texts in a foreign language. One of the strategies that may be helpful for learners is the use of graphic organizers, which Jiang and Grabe (2007) define as a "visual representation[s] of information in the text" (p.34). Indeed, the improvement of reading comprehension skills has been a benefit ascribed to these tools. Jones, Pierce and Hunter (1988) acknowledge the importance of using graphic organizers to comprehend texts. Additionally, some researchers (e.g. Goodnough \& Woods, 2002; Griffin, Duncan \& Kameenui, 2001; Robinson, Katayama, Beth, Odom, Hsieh, \& Vanderveen, 2006) have contributed to provide insight about the usefulness and effectiveness of graphic organizers in the teaching and learning process. On the other hand, summarizing is another helpful strategy to enhance students' understanding of texts; this is an advantage highlighted by Griffin et al. (2001), Idris, Baba and Abdullah (2007), Pirozzi (1995) and Singhal (2006). For this reason, both graphic organizers and summaries were the strategies chosen in this study to aid students understand the main ideas of the texts used in class.

\section{Review of the Literature}

Graphic organizers have gained attention from experts in the field of reading comprehension and content-based instruction. For example, Jones et al. (1988) argue that students who construct graphic organizers are able to understand the main ideas and details of a text, the connection between them, and the aspects that are not clear (p. 20). They also point out that these tools are important because they enhance learners' involvement in processing a text and 
help them "comprehend, summarize, and synthesize complex ideas" (p. 21). This positive point of view about the use of graphic organizers is supported by the results obtained in the studies conducted by Robinson et al. (2006), Goodnough and Woods (2002) and Griffin et al. (2001) to determine their effects on classroom environments. Authors such as Griffin et al. (2001), Idris, Baba and Abdullah (2007), Pirozzi (1995) and Singhal (2006) point to the use of summaries as a tool to show true reading comprehension. Hence, an analysis of the usefulness of both graphic organizers and summaries will be presented in order to shed light on what different authors have stated about these tools.

Robinson et al. (2006) conducted four experiments focused on the advantages of using partial and complete graphic organizers in a classroom setting, on the usefulness of these tools to help university learners to have a better performance on tests of reading comprehension, and on the impact of the performance of some partial graphic organizer tasks on the learners, specifically to take graphic organizer notes on their own. The results obtained showed that the students who completed partial graphic organizers got higher scores in examinations and quizzes covering course content in contrast to those who wrote summaries or viewed complete diagrams containing the notes that they needed to study. Additionally, a lot of learners switched from taking non-graphic notes to graphic notes. For these authors, graphic organizer tasks may help instructors to teach learners course content and relevant metacognitive skills such as identifying text structure. This investigation mainly focuses on the use of graphic organizers as study tools in content-based classroom environments dismissing the impact of their application for other reading purposes. However, if the learners in this study improved their performance on different evaluations, it means that they were able to comprehend well the texts that they read in class. Even though these authors do not provide information about the learners' perceptions about the effectiveness of the use of diagrams and the reasons why they resorted to taking graphic notes instead of non-graphic notes, it can be suggested that the format of the strategy may have played a relevant role in their improvement on text comprehension. As Robinson et al. (2006) point out, graphic organizers notes help students to focus on relevant information and to "notice important across-concept relations that are not as apparent when viewing linear forms of notes" (p. 103). Thus, learners have to deeply analyze the information in the graphic organizer to understand how the ideas are interconnected; this may enable them to grasp the main ideas of texts when implemented in class as whilereading exercises.

Goodnough and Woods (2002) focused on the use of mind maps in contentbased classes to help students understand new and difficult concepts. They carried out a 10-month interpretative case study using teacher-created as well as individual and group student-generated maps in class in order to enhance science teaching and learning. Most learners, sixth graders, perceived mind maps as fun, interesting, motivating and learning-enhancing tools. This strategy was considered a means to show their creativity. Furthermore, these students were able to increase their level of attention, better organize their thoughts and ideas, 
improve their memory, understand deeply the subject matter, have a better approach to share ideas during assessment, and improve note-taking. On the other hand, some students pointed out that interpreting them was confusing, and that they were not helpful tools to learn. Nevertheless, teachers have to take into account that satisfying all students' needs is a very difficult task. Moreover, if they find a strategy that helps all or at least the majority of learners to achieve a specific goal, they should teach it and raise awareness of the importance of its use. Compared with the research conducted by Robinson et al. (2006), the learners in both studies benefited from the use of these visual tools regardless of their different educational levels, which indicates that graphic organizers and mind maps can be useful and effective for students of dissimilar ages. However, while the study conducted by Robinson et al. (2006) involves reading comprehension, the research carried out by Goodnough and Woods (2002) focused on the use of the mind mapping strategy "to introduce new topics through teacher-generated maps created prior to instruction or during instruction" (p.7). In other words, the investigators used this strategy as a means to teach the subject matter rather than as a tool to read texts in class.

A third study that focused on the use of graphic organizers as study tools in content-based classroom environments is the one conducted by Griffin et al. (2001). Even though graphic organizers were used to teach social studies, reading comprehension was involved in the process, which differs from the use made of graphic organizers in Goodnough and Woods's research (2002). Griffin et al. (2001) wanted to find out whether "graphic organizer instruction facilitate[d] comprehension, recall, and transfer of information contained in an expository textbook" (p. 98) and whether "explicit instruction [was] necessary for independent generation and use of graphic organizers by students" (p. 98). The researchers found out that the learners receiving explicit graphic organizer instruction obtained the highest mean scores on an immediate posttest and an immediate recall measure. Additionally, students' performance on a delayed posttest and an immediate posttest was similar since the learners in all study conditions remembered about the same information (p. 105). Nevertheless, the ones who were in three treatment condition groups had a better performance on a measure transfer than those who were in the traditional basal instruction condition group, in which they were asked "to write sentences using the key vocabulary words identified in each chapter subsection" (p. 102), and to answer "what if" questions in groups before reading the text as well as post-reading literal comprehension questions. Moreover, they were instructed "to read a map without contour lines" (p. 103) and "to read a chart and analyze the data" (p. 103). These results are meaningful because they refer to the usefulness of graphic organizers to ease text comprehension; however, due to the fact that this study as well as the other two investigations previously described focus on using this strategy in contentbased lessons, the outcomes achieved may have been influenced by two different factors. These may be the explanations provided by teachers about the subject matter and the chances that the learners had to rehearse the information studied in class as well as to read from the textbooks in order to create diagrams. 
Moreover, students in the investigations conducted by Griffin et al. (2001) and Robinson et al. (2006) read texts in their native language, which is less demanding in terms of cognitive processing than reading texts in a foreign language. Indeed, in students' success in understanding main ideas and supporting details in texts written in a foreign language will depend on their own analysis of the information, on their good use of reading strategies and probably on their level of proficiency in the target language.

Unlike the authors previously cited whose point of view about the use of graphic organizers is mainly encouraging, Pirozzi's viewpoint (1995) about this strategy is more discouraging in terms of students' real comprehension of texts. In fact, he argues that diagramming does not necessarily help the reader completely understand the text because it only serves to organize textbook material and to identify the connection between different sentences and ideas in a passage. He suggests that summarizing should be used to show true comprehension of the text. Moreover, Idris et al. (2007) assert that "summarization is one of the best learning techniques to evaluate students' comprehension" (p.530). According to Gardner (1998), a "summary is a brief restatement, in [the writer's] words, of the main ideas in a reading passage" (p.254) in order to provide the reader with "an accurate sense of the content and emphasis of the original" (p.254). Probably, summaries help readers understand texts because of the effort that they have to make in order to paraphrase the most important ideas of the reading. In this research project, however, a summary will be mainly considered a short version of the original text with its main ideas. In other words, it does not matter whether the learners write the summaries in their own words or not; what really matters is whether their summaries include the most important points mentioned in the reading. Based on these aspects, it is possible to affirm that graphic organizers constitute helpful tools for students to improve their comprehension of texts and summaries are effective tools for teachers to measure their learners' understanding of texts.

Another conclusion derived from the previous information is that it seems that graphic organizers should be used as a while-reading strategy, and summaries should be implemented as a post-reading strategy. Singhal (2006), however, sees both strategies separately since she suggests that both of them can be used during the post reading stage. She states that graphic organizers are advantageous for increasing comprehension and for helping readers remember information by means of visual representations. Furthermore, she suggests that a written summary is a strategy that helps readers get main ideas and supporting details from texts, but she does not specify whether both strategies can be implemented complementarily or not. Nevertheless, due to the fact that both strategies have a similar impact on readers, it is possible to combine them to enhance students' comprehension of different types of texts. In fact, Griffin et al. (2001) concluded that providing learners with summarization training, explicit instruction or oral practice instruction as a complement to graphic organizer instruction may be a relevant factor in the design of graphic organizer instruction. Even though this comment is directed towards the use of diagrams 
in content-based classes, it reinforces the fact that both diagrams and summaries can be used together in order to help students comprehend the main ideas of texts even when they read for other purposes.

Since readers of English as a foreign language usually struggle to comprehend the main ideas of texts, educators should find a solution to help them tackle this problem. By doing this, learners will be able to feel more comfortable and confident when reading different types of texts and instructors will be capable of motivating them to keep on reading in the target language. For this reason, the primary objective of this study is to answer the following research question: How can the complementary use of partially-completed graphic organizers and summaries help students get the gist of different texts? Four sub-questions derive from this main question:

1. What factors, according to the students' perception, hinder their comprehension of the main ideas of the texts used in the interventions?

2. What are the students' perceptions, before and after the interventions, of the effectiveness of completing graphic organizers to get the gist of texts?

3. What are the students' perceptions, before and after the interventions, of the effectiveness of writing summaries to get the gist of texts?

4. What are the students' perceptions of carrying out both tasks complementarily in order to get the gist of the assigned texts?

\section{Methodology}

\section{Participants}

The study was conducted with a group of 23 students, 10 men and 13 women, taking the course LM-1032 in the Section of English for Other Majors (SIPOC) at the School of Modern Languages from the University of Costa Rica (Rodrigo Facio Campus). Most of these students were adults whose ages ranged from 18 to 40 years old. All of them were enrolled in different majors. Only one student was not enrolled in any major because she works at the university. These participants attended classes twice a week, 3 hours per day during 15 weeks.

\section{Procedures}

Before starting with the interventions, the pre-intervention questionnaire was given to the students in order to get information such as their perceptions about the use of graphic organizers and summaries (see Appendix 1). In another lesson, the researcher explained to the students what graphic organizers are and how they are used. The students were given a handout with the most relevant information about this strategy. They were also given another handout with a 
short text and its corresponding graphic organizer that the teacher created so that they analyzed it in groups. Indeed, they were asked to identify in the text the information that was provided in the graphic organizer. After they finished, the researcher asked them questions to check what they did. It is important to mention that they were not taught how to summarize because they had already been taught, in general terms, how to do it some weeks before the interventions, and they were supposed to know this from a previous course that they had to pass (LM-1030 Strategies of Reading Comprehension in English I) in order to register LM-1032. However, the teacher reviewed the characteristics that an appropriate summary should possess. After introducing both strategies, the researcher made three interventions. In each intervention, the teacher asked the students some questions about the text that was going to be provided as a pre-reading exercise to help them activate their background knowledge. Then, they were given a copy of an expository text with a partially-completed diagram. The teacher asked them to complete the graphic organizer and once they finished doing this while-reading exercise, they had to write a summary of the text as a post-reading exercise. All handouts were collected in order to check them and to make copies of them before returning them to the learners. When the handouts were returned, the teacher provided feedback about the students' performance on the completion of both exercises. The first two interventions were made consecutively; that is, they were made during the two days of the week when they attended classes. The third intervention was made a week later due to time constraints to return the second intervention checked. The teacher in the three interventions did not set a limit of time for the learners to do the tasks; that is, they were given the time that they needed to do what they were requested. Finally, the post-intervention questionnaire was given to the students in order to get information about their perception of the two tasks assigned: completing graphic organizers and writing summaries of the texts that they read in class. (see Appendix 2).

In relation to the interventions, in the first one, students were given a reading taken from Pirozzi (1995). The teacher included a diagram with seven cells that she created; three of the cells were in blank so that the learners completed them. For the second intervention, the learners were given a text that was chosen by a student who brought it as homework the second day of classes because the teacher wanted to have an idea of the topics that they liked to read. The researcher decided to pick one of these readings in order to take into account their interests. In addition, they were provided with a copy of the diagram with fourteen cells that the teacher created; eight out of the fourteen cells were in blank. For the third intervention, the instructor gave them a reading from Scientific American magazine, which was a source used to choose some of the readings that they analyzed in class. Furthermore, students were given a teacher-created diagram with 18 cells. For this intervention, students were provided with just four complete cells. It is also essential to emphasize that seven cells correspond to aspects that were listed in the text, which means that the learners did not have to make an effort to look for them in different parts of the text; therefore, those cells were counted as one in order to analyze the data. In other words, 
instead of counting a total of fourteen cells, the researcher just counted eight in order to grade the diagrams.

\section{Instruments}

To collect the data, eight instruments were designed: a pre-intervention questionnaire, a post-intervention questionnaire, three handouts used in each of the interventions (they are not included in the Appendixes section, but they are available upon request), a scale of evaluation for each of the three graphic organizers (see Appendix 3), a scale of evaluation for the summaries (see Appendix 4), and a list in order to collect administrative data (e.g., the number of students who participated in each intervention, the number of cells that they correctly completed in each graphic organizer and the qualitative grades that they obtained in both the graphic organizers and the summaries).

\section{Results and Discussion}

\section{Results and discussion for the first intervention}

Based on the results obtained in the first intervention, three tendencies were found: students whose performance on both the graphic organizer and the summary was the same, learners who performed better on the summaries, and students who performed better on the completion of the graphic organizer. Figure 1 shows in detail the results for each tendency.

Figure 1

Tendencies derived from the comparison of students' performance on the graphic organizer as well as in the summary

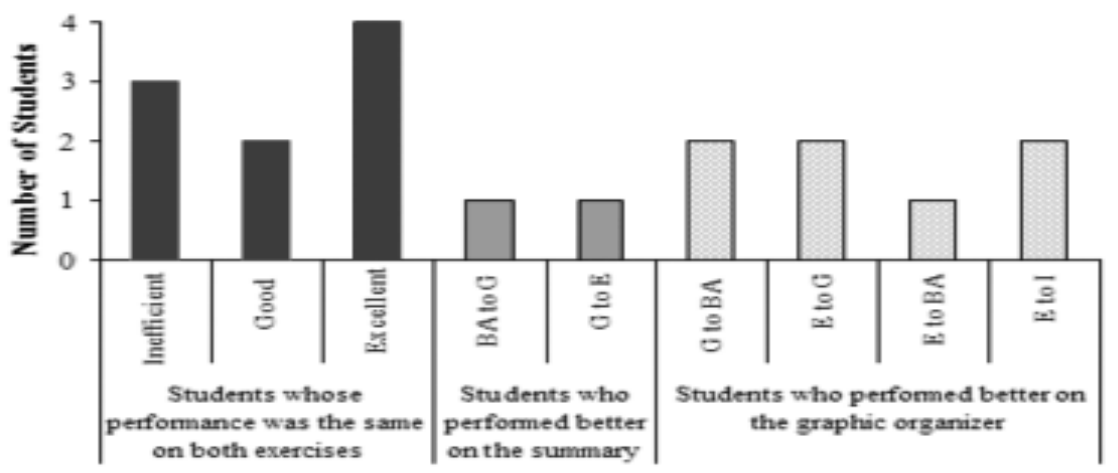

Tendencies 
As Figure 1 shows, students who obtained "excellent" and "good" in the graphic organizer as well as in the summary showed complete or almost complete understanding of the gist of the text; however, three out of nine learners in this tendency had an "inefficient" performance on both exercises, which means that they did not understand the main ideas of the reading. It is important to stress that these three learners had a low level of English, which could have affected their performance on both exercises. Indeed, their lack of vocabulary and understanding of grammatical structures in English could have hindered their comprehension of the text as well as their understanding of its rhetorical structure, which did not let them differentiate its main ideas from secondary ones in order to complete the graphic organizer and to write the summary.

In the case of those students who had a better performance on the summary than in the graphic organizer, they probably improved their understanding of the gist of the reading due to the fact that they had to read the text more than twice in order to do both exercises. In the case of those learners who had a better performance on the graphic organizer than in the summary, the least serious case was the one in which the students had an "excellent" performance on the completion of the graphic organizer, but they received "good" in the summary because these learners were able to understand most of the main points of the text. Nevertheless, the other learners showed a lack of understanding of its gist. In fact, they had different problems. One of them was that they misinterpreted the information provided in the reading. Moreover, they lacked supporting details, and in some cases they provided information that was not supported by the text. Therefore, teachers should not merely rely on graphic organizers to measure how well students understand the gist of texts. As Pirozzi (1995) argues, diagramming does not necessarily help the reader completely understand the text because it mainly serves to identify the connection between different sentences and ideas in a passage; hence, he recommends the use of summarizing as a strategy that serves to show true comprehension of the text. Educators should take into account this recommendation especially because it seems that summaries are helpful tools for them in order to evaluate learners' comprehension of texts as Idris et al. (2007) assert.

An interesting fact arises from the separated analysis of the results of the graphic organizer and the summary. Taking into account the "excellent" and "good" performances as a whole, more students had a high performance on the summary than in the graphic organizer. However, they represent less than the $50 \%$ of the participants in this intervention, which means that the majority of the learners did not understand well the gist of the text. Figure 2 shows in detail this fact. 
Figure 2

Students' performance on the graphic organizer and the summary of the first intervention

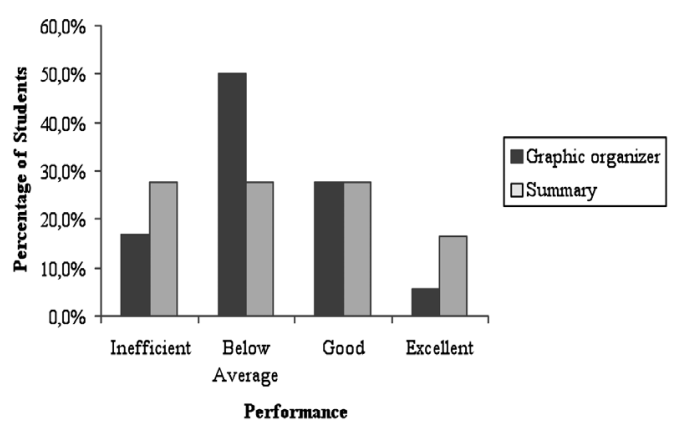

Most of the students who showed a richer understanding of the text were the ones with a good level of English, or the ones who attained higher grades in the course's evaluations. Nevertheless, there were some who had a low level of English and who struggled to pass the quizzes and exams, but they still had a high performance on the summary, which suggests that the use of a visual aid such as the graphic organizer could have exerted a positive influence on their comprehension of texts, which was then evident in their summaries. On the contrary, learners who had a poor understanding of the main ideas of the reading may have been affected negatively by their level of proficiency in English as well as by the complexity of the rhetorical structure of the text.

\section{Results and discussion for the second intervention}

The tendencies that were analyzed in the first intervention were also found in this intervention. However, there are variations in terms of the different qualitative grades that the students attained. Compared with the results of the first intervention in terms of the learners whose performance was the same on both the graphic organizer and the summary, the results in this intervention improved in the sense that none of the participants had an "inefficient" performance on both exercises, but the number of students who obtained "excellent" in both exercises decreased from four to one. Regarding the second and third tendencies, similar to the results in the first intervention, the number of learners who had a better performance on the summary was small compared to the number of students who had a better performance on the graphic organizer. As Figure 3 shows, the majority of learners in the third tendency had either "good" or "excellent" performances on the graphic organizers, but most of them went down to "below average" and" inefficient" in the summary. This seems to indicate that even though they were able to understand the connections among the ideas provided in the graphic organizer, they were not able to take advantage of this 
tool in order to write the summary although it included the main ideas and supporting details of the text. In general terms, they showed that they understood the main idea of the text, but they failed to provide enough supporting details, and the ones that they mentioned were irrelevant, too general, misinterpreted or not supported by the text.

Figure 3

Tendencies derived from the comparison of students' performance on the graphic organizer as well as the summary of the second intervention

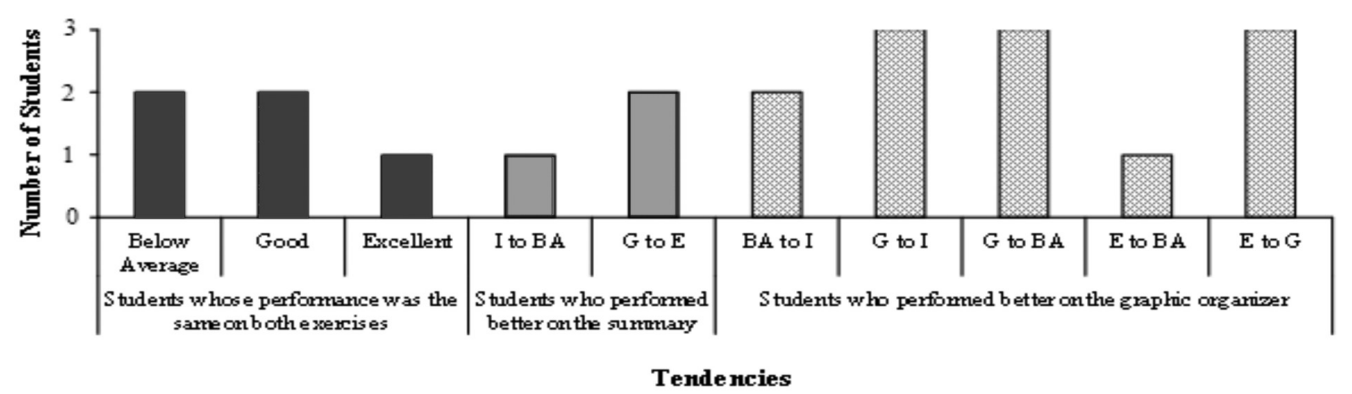

Taking into account the "excellent" and "good" performances as a whole, more learners had a high performance on the graphic organizer than in the summary, which is the opposite of what happened in the first intervention. To be specific, $75 \%$ of the participants in this intervention had an outstanding performance on the graphic organizer in contrast to the $40 \%$ of the students who wrote "good" and "excellent" summaries. This indicates that less than half of the 20 learners who participated in this intervention understood the main ideas of the text with their corresponding supporting details. Figure 4 shows in detail this fact.

Figure 4

Students' performance on the graphic organizer and the summary of the second intervention

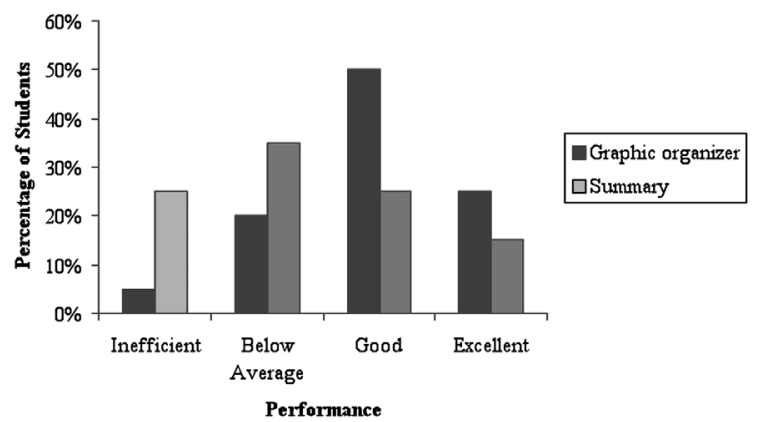


The rest of the students who had an "inefficient" or "average" performance on the summary were able to identify the main idea of the text, but they had problems with the supporting details. Probably, the text was very complex in terms of structure and this factor caused them problems to provide the accurate supporting details. Another factor that may have exerted a negative influence on their performance was the space provided in the handout to write the summary. Even though they were told that they could use the other side of the page if they needed more space, most of them tried to write the summary in the eight lines provided. This situation constitutes a drawback because there are learners whose handwriting is big, and they provided information that was too general, or excluded important details in order to write the summary on the space given. Consequently, teachers should be careful when choosing the layout of the handouts that they create because this is a factor that can affect students' performance on the task assigned.

\section{Results and discussion for the third intervention}

The three tendencies that were analyzed in the first and second interventions were also found in this last intervention. Nevertheless, variations in terms of the different qualitative grades that the students attained were also found compared to the previous two interventions. Figure 5 shows this in detail.

Figure 5

Tendencies derived from the comparison of students' performance on the graphic organizer and summary of the third intervention

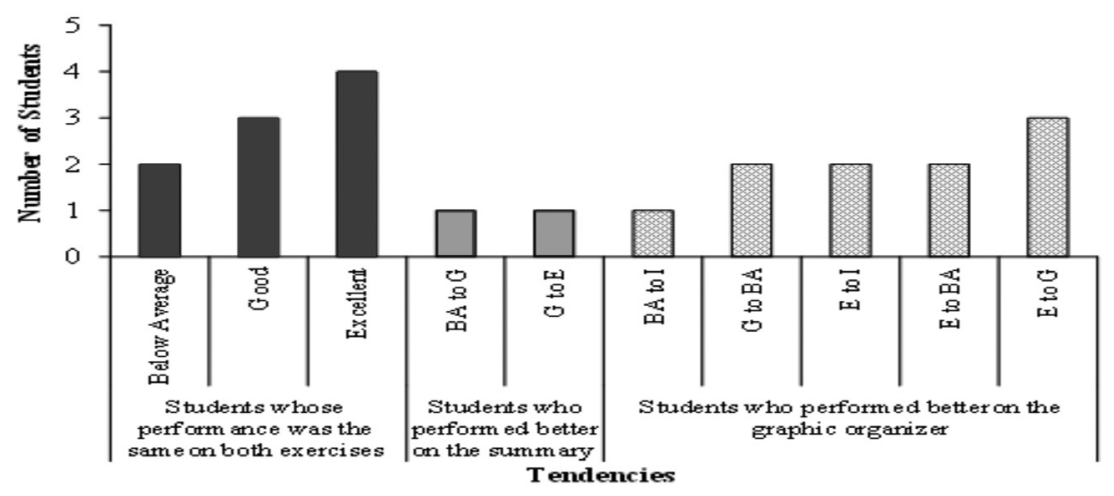

Compared with the results of the second intervention in terms of the students whose performance was the same on both the graphic organizer and the summary, there were no variations in the grades obtained; that is, their performances ranged from "below average" to "excellent." However, the number of learners who had an "excellent" performance increased to four, which was the 
same number obtained in the first intervention. Probably the third diagram was clearer to interpret and to complete than the second one in terms of connections among ideas and the headings provided, and the reading was easier for them to understand. Both factors may have contributed in their "excellent" performance on both exercises.

In the case of the second and third tendencies, the results are similar to the ones in the first and second interventions; in fact, the number of students who had a better performance on the summary was small compared to the number of students who had a better performance on the graphic organizer. In the case of the second tendency, the patterns of improvement were the same as those in the first intervention; that is, they ranged from "below average" to "good" and from "good" to "excellent." In terms of the third tendency, the majority of learners had either "good" or "excellent" performances on the graphic organizer, but most of them went down to "below average" in the summary. Even though they stated the main idea of the text, they failed to provide enough supporting details, which can also be related to the limited space provided to write the summary or their willingness to write a complete summary. In other words, it is easier and faster to write very general ideas than going into details especially when they invested a lot of time to complete the graphic organizers. They probably felt tired to continue working with the summary because they had already worked on other reading comprehension exercises before carrying out the two tasks for this intervention. Another possible explanation is that many students prefer to do reading comprehension exercises in which they just have to choose options instead of writing, which is the skill that they had to use for both the graphic organizer and the summary.

Figure 6

Students' performance on the graphic organizer and the summary of the third intervention

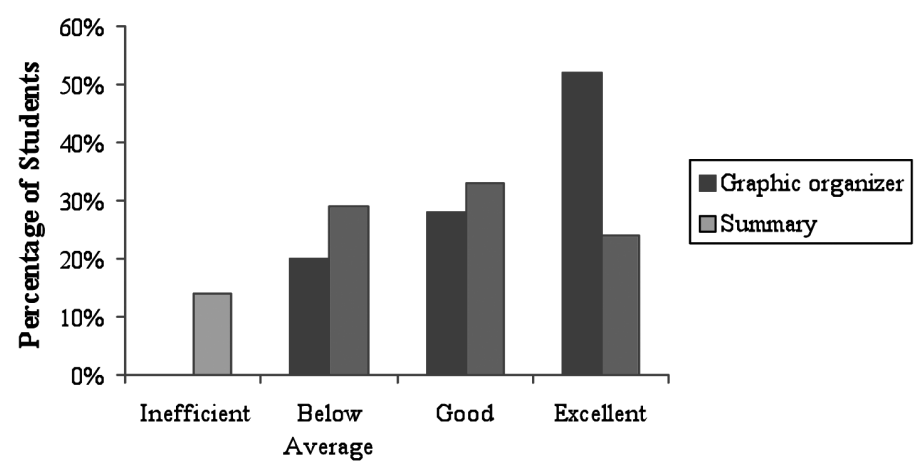

Performance 
Taking into account the "excellent" and "good" performances as a whole, more students had a higher performance on the graphic organizer than in the summary as shown in Figure 6, which is similar to the result obtained in the second intervention. To be specific, $80 \%$ of the participants in this intervention had an outstanding performance on the graphic organizer in contrast to the 57\% of the learners who wrote between good and excellent summaries.

Compared with the results in the first and the second interventions, there was an improvement in terms of the overall performance on the graphic organizer as well as in the summary. In this particular case, more than a half of the participants were able to understand the gist of the text, which is the opposite of what happened in the first and second interventions. It seems that constant practice helps students to better analyze the text in order to differentiate main ideas from irrelevant information. Nevertheless, their improvement could have been linked to the level of complexity of the reading in terms of vocabulary as well as in terms of its grammatical and rhetorical structure. Another factor that may have exerted an influence on their improvement is the topic of the reading since many of them have experienced sleep debt (the text was about sleep deprivation), which provides them with enough background knowledge in order to interact with the text. This situation allows them to understand its gist more accurately than when they cannot establish a connection with the topic of the text.

Despite the uncertainties related to the factors that influenced the learners' improvement in their performance on both exercises, the results obtained contribute to reinforce the relevance of the assertion made by Idris et al. (2007) about the use of summarization as a tool to evaluate students' comprehension. Without the summaries, the results would have probably been more dramatic in terms of the understanding of the gist of the reading. It is advisable for teachers not to rely on the students' performance to complete graphic organizers to measure how well they understand the main ideas and supporting details of the texts used in class. On the other hand, those students who had an inefficient or below average performance on the summary referred to the main idea of the text, but the major problem that they had was with the supporting details. Compared with the second intervention, they lacked supporting details, and the ones that they wrote were too general to help the reader understand what the text is about.

\section{Results and discussion for sub-question 1}

Students were asked in the post-intervention questionnaire what factors exerted a negative influence on their comprehension of the main ideas in the texts that were provided. The factors that they mentioned were divided into three categories: factors related to their knowledge of the language, factors pertaining to the reading, and other factors. Lack of vocabulary was the most troublesome factor for them, as indicated in Figure 7. 
Figure 7

Factors that according to the students' perception hindered their comprehension of the gist of the text

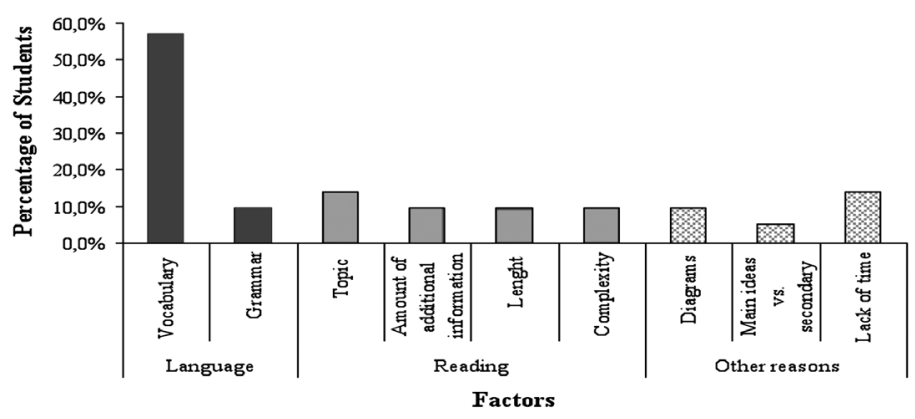

However, other aspects such as the topic of the readings and lack of time constituted limitations for them in order to comprehend the main ideas of the text. Even though they were not given a specific amount of time to complete the exercises, some of the learners probably felt that they needed more time in order to translate the reading. Indeed, many of them still depend a lot on the dictionary because they prefer to translate the majority of unknown terms into Spanish in order to have an idea of what the text is about. Moreover, their frustration about time may have been related to the fact that they knew that they had to finish both exercises because their handouts were going to be collected. When they know that the teacher will not do this, some decide to do as much as they can, but they do not care if they are not able to finish or not.

As it can be observed in Figure 7, other factors such as the amount of additional or irrelevant information provided in the texts as well as the incapability to differentiate between main and secondary ideas affected learners to understand the gist of the texts. They also mentioned that their length, and their complexity constituted constraints to achieve this goal. Finally, the use of diagrams had a negative effect on some learners' comprehension of the reading. A student in particular mentioned that the diagram was confusing; hence, she/he was even more confused to comprehend the text. This is similar to what happened in Goodnough and Woods's study (2002). Even though some students appreciated the use of mind maps in class, there were others who had a negative perception of them. Due to the fact that all people think and learn differently, it would be advisable for teachers to let their learners design their own graphic organizers. However, instructors should take into account that the use of graphic organizers may be related to the students' learning styles. Therefore, they should teach different strategies so that their students choose the one that fulfills their needs and that helps them have a better understanding of the gist of texts in English. Moreover, teachers should look for solutions in order to tackle the kinds of problems that the students mentioned. For example, if the problem is with vocabulary, they should look for simpler readings; if the learners' level of 
proficiency in English is low, or if they want to use more complex readings, providing a glossary can be a solution to help learners comprehend the information provided more accurately. These types of solutions should match the level and the goals of the course, and teachers should also encourage students to look for their own solutions so that they become more autonomous.

\section{Results and discussion for sub-question 2}

This section presents the results to answer the question about the students' perceptions, before and after the interventions, of the effectiveness of completing graphic organizers to get the gist of texts. The first aspect to consider is that even though the majority of the participants in the study never or almost never use graphic organizers to get the gist of texts in English as Table 1 shows, more than a half of the 22 students who completed the pre-intervention questionnaire were positive about the degree of usefulness of graphic organizers. Table 2 shows this in detail.

Table 1

Percentage of Frequency with which the Participants Use Graphic Organizers to Read Texts in English according to the Pre-Intervention Questionnaire

\begin{tabular}{ccccc}
\hline Frequency & Never & Almost never & Almost always & Always \\
\hline $\begin{array}{c}\text { Percentage of } \\
\text { students }\end{array}$ & $59 \%$ & $32 \%$ & $9 \%$ & $0 \%$ \\
\hline
\end{tabular}

Table 2

Perception about the Degree of Usefulness of Graphic Organizers according to the Pre-Intervention Questionnaire

\begin{tabular}{ccccc}
\hline Degree of Usefulness & Very useful & Useful & Not very useful & Useless \\
\hline $\begin{array}{c}\text { Percentage of } \\
\text { students }\end{array}$ & $14 \%$ & $41 \%$ & $41 \%$ & $4 \%$ \\
\hline
\end{tabular}

When they were asked whether the use of graphic organizers would help them understand the main ideas of a text or not, the majority of learners answered affirmatively the question, which is shown in Table 3. Compared with their perception about the degree of usefulness of this tool, there is a dramatic increase in terms of their positive view about graphic organizers. 
Table 3

Answers about the Perception of Graphic Organizers' Usefulness to Understand the Gist of Texts according to the Pre-Intervention Questionnaire

\begin{tabular}{ccc}
\hline Answer & Yes & No \\
\hline Percentage of students & $82 \%$ & $18 \%$ \\
\hline
\end{tabular}

Those who answered affirmatively pointed out different factors. The more salient ones refer to the usefulness of graphic organizers as a means to better summarize the text, and to order its ideas logically. This is in agreement with what Jones et al. (1988) argue, so there is awareness of the possible benefits ascribed to this reading comprehension strategy. Additionally, a student also considered the use of graphic organizers as an easy, entertaining and comprehensive way to identify main ideas. Finally, it was stated that these tools would help readers establish a connection between ideas, and to get acquainted with the text because of the time invested to work with it. Time, however, was an issue among those learners who answered negatively the question. In fact, a student wrote that graphic organizers would not help the reader understand the main ideas of the text because it takes time to find them. Another reason in disfavor of the usefulness of these tools is related to the fact that they are complex, and this particular student mentioned that she/he prefers to highlight the main ideas instead of creating graphic organizers.

In the post-intervention questionnaire, students were asked whether the use of graphic organizers helped them understand the gist of the texts or not. Compared with the results obtained in the pre-intervention questionnaire, their perception about the usefulness of these tools did not vary in the sense that the percentages of positive and negative answers did not vary. The only variation is observed in Table 4 since there was a student who did not take a defined position about her/his experience by completing graphic organizers.

Table 4

Answers about the Perception of Graphic Organizers' Usefulness to Understand the Gist of Texts according to the Post-Intervention Questionnaire

\begin{tabular}{cccc}
\hline Answer & Yes & No & More or less \\
\hline Percentage of students & $85 \%$ & $10 \%$ & $5 \%$ \\
\hline
\end{tabular}

It seems that their expectations about the helpfulness of graphic organizers to get the gist of texts were fulfilled due to the fact that their perception remained positive. As Figure 8 shows, there were three salient points that justified their affirmative responses. First, these tools help understand the reading in general terms. Second, they help them distinguish between minor and important details. 
Third, graphic organizers let them organize the ideas of the texts. Another aspect that was highlighted is that these tools facilitated their summarization of the text. These aspects are in agreement with what Jones et al. (1988) as well as Robinson et al. (2006) point out about the usefulness of graphic organizers.

Figure 8

Students' positive responses about the usefulness of completing the three graphic organizers

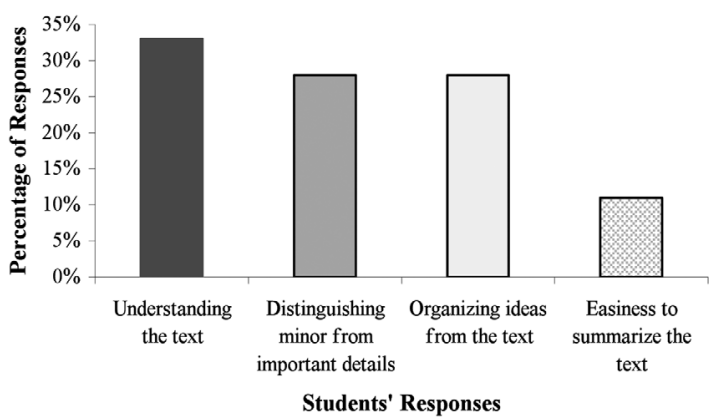

Regarding the negative responses, one aspect that was emphasized in both the pre-intervention and the post-intervention questionnaires refers to the difficulty to understand graphic organizers, which also hindered their comprehension of the text. As figure 9 shows, the percentage of responses is small, but still it constitutes a reminder for teachers that fulfilling all learners' needs is complicated; consequently, they should teach different strategies to help students improve their reading comprehension skills.

Figure 9

Students' negative responses about the usefulness of completing the three graphic organizers

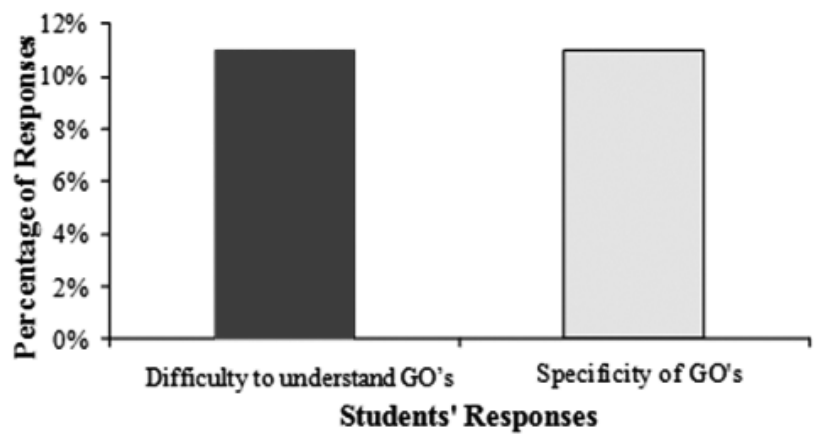


Another factor that students pointed out as a hindrance to understand the gist of the text was the level of specificity of the graphic organizers. Some of them stated that the diagrams were very specific; therefore, they had problems to find the information in the text that completed the blank cells, and this specificity led them to make mistakes.

In general terms, as Table 5 shows, $86 \%$ of the 21 learners who completed the post-intervention questionnaire were positive about the degree of usefulness of graphic organizers. There was an improvement in their perceptions compared with the pre-intervention questionnaire since none of them considered this strategy useless, and a small percentage of students considered that it is not very useful. This result is significant since more learners acknowledged the value of the use of graphic organizers to read in English.

Table 5

Perception about the Degree of Usefulness of Graphic Organizers according to the Post-intervention Questionnaire

\begin{tabular}{ccccc}
\hline Degree of Usefulness & Very useful & Useful & Not very useful & Useless \\
\hline $\begin{array}{c}\text { Percentage of } \\
\text { students }\end{array}$ & $24 \%$ & $62 \%$ & $14 \%$ & $0 \%$ \\
\hline
\end{tabular}

\section{Results and discussion for sub-question 3}

This section presents the results to answer the question about the students' perceptions, before and after the interventions, of the effectiveness of writing summaries to get the gist of texts. Similar to the results of the frequency with which students use graphic organizers to read texts in English, the frequency with which the learners write summaries after reading texts in English is dramatically low. Indeed, $64 \%$ of students indicated that they almost never use this strategy and $34 \%$ of the participants never use it. Although the reasons why they do not use either of the two strategies are unknown, they need more instruction and practice on how to use and exploit these tools so that they improve their reading skills and their comprehension of texts especially because their perception about the degree of usefulness of summaries is mostly encouraging. As Table 6 indicates, the majority of students consider that summaries are either useful or very useful. 
Table 6

Perception about the Degree of Usefulness of Summaries according to the Pre-Intervention Questionnaire

\begin{tabular}{cccccc}
\hline $\begin{array}{c}\text { Degree of } \\
\text { Usefulness }\end{array}$ & Very useful & Useful & $\begin{array}{c}\text { Not very } \\
\text { useful }\end{array}$ & Useless & No Answer \\
\hline $\begin{array}{c}\text { Percentage of } \\
\text { students }\end{array}$ & $41 \%$ & $36 \%$ & $14 \%$ & $4,5 \%$ & $4,5 \%$ \\
\hline
\end{tabular}

Students were asked whether summarizing a text would help them understand its main ideas, and 91\% of the learners answered positively. The most salient answer referred to its helpfulness to dismiss irrelevant information. Other aspects were highlighted. A student, for example, pointed out that by means of this tool, the information could be processed and assimilated. There was a male learner who stated that it simplifies the reading, but he did not develop this answer. Perhaps, he meant by simplification the process of interpreting ideas, which can be presented by means of complex structures and technical vocabulary, in order to present them in simpler and even colloquial terms. Another student considered that summarizing helps to outline the text. Finally, there was a student who indicated that writing a summary involves re-reading the text, which contributes to understand it much better. At least, many of them were aware of the possible benefits that summarization provide to their comprehension of texts. However, there were two students who answered negatively. One of them stressed that she/he preferred to highlight texts, which was the same that she/he answered in the question about the usefulness of graphic organizers. It seems that she/ he is determined to use this strategy rather than others. Furthermore, another student asked an interesting question: "If the summary includes the main ideas of the text, and if one does not understand them, how can one write a summary?" At least in class, they are provided with readings that are accessible for them in terms of complexity of English. This is a reminder for teachers in order to be careful when choosing texts. In other words, the readings should be suitable according to their learners' level of English and needs. To get this type of information, teachers should administer a diagnostic test at the very beginning of the course, and they should also conduct a survey to know what the learners' field of study and reading interests are. If instructors do not take this into account, their students will probably fail to achieve the desired goal of understanding the gist of the texts, and they will surely feel frustrated to read in English.

In the post-intervention questionnaire, students were asked whether summaries helped them to understand the gist of the texts or not. Compared with the results obtained in the pre-intervention questionnaire, their perception about the usefulness of these tools did not vary. In fact, 95\% percent out of the 21 learners who answered this question answered affirmatively. However, there was a student who did not take a strong position, and she/he provided a "more or less" answer. 
This result is encouraging because it seems that their expectations about the use of these tools were fulfilled. In fact, some of their responses reinforce what they stated in the pre-intervention questionnaire. For example, it was pointed out that summaries force them to be precise in order to synthesize the text without omitting main ideas. It was also stated that summaries let them have a holistic view of the text, organize its information, simplify its ideas, establish a connection between ideas, speed up the reading process, review and remember information. Regarding the student who answered "more or less," she/ he stated that the usefulness of summaries depends on the overall understanding of the text. Probably, this is related to the level of complexity of the vocabulary of the text and its organization, which is a factor that obviously exerts an influence on their comprehension depending on their level of proficiency of English. The most important aspect about these results is that awareness about the usefulness of this tool was raised, and that they did not change their positive perception about its use. What changed was their perception about the degree of usefulness of summaries. As Table 7 shows, compared with the results obtained in the pre-intervention questionnaire, the percentage of learners who considered summaries very useful decreased from 41 to 28 ; nevertheless, the reason is unknown. The encouraging part is that $85 \%$ of the 21 students who completed the post-intervention questionnaire were positive about the degree of its usefulness, which is similar to the results obtained in the pre-intervention questionnaire.

Table 7

Perception about the Degree of Usefulness of Summaries according to the Post-intervention Questionnaire

\begin{tabular}{cccccc}
\hline Degree of Usefulness & Very useful & Useful & $\begin{array}{c}\text { Not very } \\
\text { useful }\end{array}$ & Useless & No answer \\
\hline $\begin{array}{c}\text { Percentage of } \\
\text { students }\end{array}$ & $28 \%$ & $57 \%$ & $10 \%$ & $0 \%$ & $5 \%$ \\
\hline
\end{tabular}

\section{Results and discussion for sub-question 4}

After analyzing the learners' perception about the use of graphic organizers and summaries separately, it was fundamental for the researcher to know their perception about the degree of necessity of using both strategies complementarily. As Table 11 shows, the results are encouraging since they acknowledged that it was necessary and very necessary to use them complementarily to understand the main ideas of the readings. 
Table 8

Perception about the Degree of Necessity of Using Graphic Organizer and Summaries Complementarily to Get the Gist of the Assigned Texts according to the Post-intervention Questionnaire

\begin{tabular}{ccccc}
\hline Degree of Necessity & $\begin{array}{c}\text { Very } \\
\text { necessary }\end{array}$ & Necessary & Unnecessary & $\begin{array}{c}\text { Totally } \\
\text { unnecessary }\end{array}$ \\
\hline Percentage of students & $29 \%$ & $62 \%$ & $9 \%$ & $0 \%$ \\
\hline
\end{tabular}

It seems that using graphic organizers as a while-reading strategy followed by summaries as a post-reading strategy helps students to have a better understanding of the gist of the text. Therefore, using them together seems to be an effective way to address the learners' need of improving their comprehension of texts rather than using them separately. Nevertheless, studies on the effectiveness of using both strategies together or separately should be conducted in order to determine the effectiveness and usefulness of both options.

\section{Conclusions}

It seems that the complementary use of both strategies helps learners understand the gist of texts especially because students improved their performance on the third intervention in both the graphic organizer and the summary compared to their performance on the first and second interventions. It seems that constant practice helps learners to better analyze the text in order to differentiate main ideas from irrelevant information. However, there were students who had high performances on the graphic organizers, but they showed their lack of comprehension of the main ideas of the text by providing information that was extremely general, information that was misinterpreted, or information that was not supported by the text. Moreover, there were cases in which supporting details were missing. Consequently, summarizing is an effective strategy for learners to show true comprehension of text and it is a useful tool for teachers to evaluate their students' comprehension.

It was noticed that there are certain factors that hinder students' comprehension of texts, such as their lack of vocabulary, and their inability to differentiate main ideas from irrelevant information. Moreover, the length, the complexity and the topics of the readings can exert a negative influence too; hence, teachers should look for solutions in order to tackle these types of problems. Teachers should start by choosing readings that are suitable for the students' level of proficiency in the target language. Once they teach different reading strategies, they should progressively provide students with more complex texts. The idea is to challenge students so that they can improve their reading skills and they become more autonomous. To achieve this, scaffolding is very important. Because the topic of the readings is also relevant, teachers should help 
learners activate their background knowledge so that they establish a connection with the text. Additionally, instructors should provide sufficient instruction on how to use graphic organizers and how to write concise, coherent and effective summaries, and they should give learners enough time to carry out both tasks. Nevertheless, they should keep in mind that it is difficult to please learners and to fulfill all their needs; therefore, teachers should teach different strategies to help students improve their reading comprehension skills based on their learning styles. It is also advisable for researchers interested in this topic to conduct studies in which there is a control group and a monitor group in order to compare results about the students' performance on summaries with or without completing graphic organizers before. Another suggestion is to ask students to complete graphic organizers designed by the teachers as well as to design their own diagrams to compare their perceptions of both tasks.

Despite the problems that the learners' encountered, their perception about the usefulness of both strategies was highly positive before and after the interventions. This result is significant since more students acknowledged the value of the use of graphic organizers to read in English. For this reason, educators should raise awareness about the relevance of using these types of strategies to read texts in English, and they should also encourage students to use them in and outside the class.

\section{Limitations and Recommendations}

One of the limitations to develop this project was the lack of information about the students' actual level of English proficiency because this is a key aspect to consider when analyzing the reasons why readers are unable to understand the gist of texts. Furthermore, even though summarizing should be addressed in the course, this topic is superficially developed in class because students are supposed to learn it in a previous course. Moreover, lack of time was also an issue because there was not enough time for the application of the instruments and the development of the project. When the researcher conducted the study, she had already given instruction on writing summaries one or two weeks before the interventions, and the students were learning other types of discourse rather than exposition, which was the type of discourse of the three readings chosen for the interventions. Neither there was enough time to give students more instruction on how to use and complete graphic organizers and to write summaries, nor there was space to provide them with enough feedback after the interventions. In fact, the researcher could only make three interventions by providing students with partially-completed organizers as while reading activities. Thus, if other researchers attempted to do a similar work, it is suggested to ask students to build their own graphic organizers after practicing with partial-completed diagrams to compare the results obtained in the interventions in terms of their perception about the usefulness of graphic organizers to understand the gist of texts, and their performance on both tasks. 
Attendance was also an issue because it was irregular. This situation affects the results in the sense that there were students who only participated in one or two interventions, and the investigator cannot measure if they improve or worsen their performances on both graphic organizers and summaries.

Another limitation was providing learners with a small space to write the summaries. It was noted that students who used more than the space given were the ones who had "good" or "excellent" performances compared to the learners who only used the few lines available. There were cases in which students wrote very good summaries without exceeding the space provided, but they had small handwriting. For further research, students should be given more space to write so that they do not feel tempted to provide very general ideas to stick to what they have in the handout especially because there are students who have big handwriting.

\section{Bbliography}

Gardner, P. (1998). New directions: An integrated approach to reading, writing, and critical thinking. New York: Cambridge University Press.

Goodnough, K., \& Woods, R. (2002).Student and teacher perceptions of mind mapping: A middle school case study. Retrieved May 21, 2011, from http://www. eric.ed.gov/ERICWebPortal/search/detailmini.jsp?_nfpb=true\&_\&ERICExtSearch_ SearchValue_0=ED470970\&ERICExtSearch_SearchType_0=no\&accno=ED470970

Griffin, C., Duncan, L., \& Kameenui, E. (2001). Effects of graphic organizer instruction on fifth-grade students. Journal of Educational Research, 89(2), 98-107.

Idris, N., Baba, S., \& Abdullah, R. (2007). Using heuristic rules from sentence decomposition of experts' summaries to detect students' summarizing strategies. Proceedings of World Academy of Science: Engineering \& Technology, $36,530-534$.

Jiang, X., \& Grabe, W. (2007). Graphic organizers in reading instruction: Research findings and issues. Reading in a Foreign Language. 19(1), 34-55.

Jones, B. F., Pierce, J., \& Hunter, B. (1988). Teaching students to construct graphic representations. Educational Leadership, 46(4), 20-25.

Langdon, C., \& Chou, V. (2001). Teaching High School Students to Identify Main Ideas in Expository Text. Journal of Educational Research. 78(2), 114-118.

Pirozzi, R. (1995). Strategies for reading and study skills. Chicago, Illinois: NTC Publishing Group.

Robinson, D.H., Katayama, A. D., Beth, A., Odom, S., Hsieh, Y., \& Vanderveen, A. (2006). Increasing text comprehension and graphic note taking using a partial graphic organizer. Journal of Educational Research, 100(2), 103-111. Singhal, M. (2006). Teaching reading to adult second language learners: Theoretical foundations, pedagogical applications, and current issues. Lowell, MA: The Reading Matrix Inc. 


\section{Appendix 1}

\section{Questionnaire about Reading Strategies}

Before you answer this questionnaire, thank you for investing some time to provide information for a research Project. Your answers to the questions below will be totally anonymous and confidential.

Gender: M $\mathrm{F}$ / Age: / Major:

PART I. Instructions: Mark an X in the option that best answers the questions below.

1. When you read in English, is it difficult for you to understand the main idea(s) of a text?
a. ( ) never
b. ( ) almost never
c. ( ) almost always
d. () always Why?

2. How often do you use graphic organizers to read texts in English?
a. ( ) never
b. () almost never
c. ( ) almost always
d. ( ) always

3. How often do you write summaries after reading a text in English?

a. ( ) never

b. () almost never

c. ( ) almost always

d. () always

PART II. Instructions: Answer the following questions.

1. Do you think that the use of graphic organizers helps you or would help you to get the gist of a text? Why? Why not?

2. Do you think that summarizing a text helps you or would help you to get the gist of a text? Why? Why not? 
PART III. Instructions: There is a chart presented below that is divided into three parts. Based on the column that is in the middle: "Strategy," mark an $\mathrm{X}$ to indicate what you think about the level of usefulness of the strategy (left column) and another $\mathrm{X}$ to indicate what the implementation of that strategy to read a text in English would make you feel (right column). Choose only ONE option in each case.

For example:

\begin{tabular}{|c|c|c|c|c|c|c|c|c|}
\hline \multicolumn{4}{|c|}{ I think that the strategy is... } & \multirow[t]{2}{*}{ Strategy } & \multicolumn{4}{|c|}{$\begin{array}{c}\text { Implementing this strategy to get the gist of a } \\
\text { text makes me feel... }\end{array}$} \\
\hline \multirow[t]{2}{*}{$\begin{array}{l}\text { Very use- } \\
\quad \text { ful }\end{array}$} & Useful & $\begin{array}{l}\text { A little } \\
\text { useful }\end{array}$ & Useless & & $\begin{array}{c}\text { Very } \\
\text { comfort- } \\
\text { able }\end{array}$ & $\begin{array}{l}\text { Comfort- } \\
\text { able }\end{array}$ & $\begin{array}{l}\text { A little } \\
\text { comfort- } \\
\text { able }\end{array}$ & $\begin{array}{l}\text { Uncom- } \\
\text { fortable }\end{array}$ \\
\hline & $\mathrm{X}$ & & & Outlining & & $\mathrm{X}$ & & \\
\hline \multicolumn{4}{|c|}{ I think that the strategy is... } & Strategy & \multicolumn{4}{|c|}{$\begin{array}{c}\text { Implementing this strategy to get the gist of a } \\
\text { text makes me feel... }\end{array}$} \\
\hline \multirow[t]{3}{*}{$\begin{array}{l}\text { Very } \\
\text { useful }\end{array}$} & Useful & $\begin{array}{l}\text { A little } \\
\text { useful }\end{array}$ & Useless & & $\begin{array}{l}\text { Very com- } \\
\text { fortable }\end{array}$ & $\begin{array}{l}\text { Comfort- } \\
\text { able }\end{array}$ & $\begin{array}{c}\text { A little } \\
\text { comfort- } \\
\text { able }\end{array}$ & $\begin{array}{l}\text { Uncom- } \\
\text { fortable }\end{array}$ \\
\hline & & & & $\begin{array}{c}\text { Graphic } \\
\text { organizer }\end{array}$ & & & & \\
\hline & & & & Summary & & & & \\
\hline
\end{tabular}

\section{Appendix 2}

\section{Questionnaire about Reading Strategies}

Before you answer this questionnaire, thank you for investing some time to provide information for a research Project. Your answers to the questions below will be totally anonymous and confidential.

Gender: M $\mathrm{F}$ / Age: / Major:

PART I. Instructions: Mark an X in the option that best answers the questions below.

1. How many graphic organizers with their corresponding summaries did you do in class?
a. ( ) 1
b. ( ) 2
c. () 3 
2. I think that doing the graphic organizer and the summary for the texts I read was
a. ( ) totally necessary
b. ( ) necessary
c. ( ) unnecessary
d. ( ) totally unnecessary to understand the gist of the text.

PART II. Instructions: Answer the following questions.

After completing the graphic organizers and writing the summaries of the texts assigned in class:

1. Do you think that the use of graphic organizers helped you to understand the gist of the texts? Why? Why not?

2. Do you think that summarizing a text helped you to understand its gist? Why? Why not?

3. What factors do you think exerted a negative influence to understand the gist of the texts assigned in class?

PART III. Instructions: There is a chart presented below that is divided into three parts. Based on the column that is in the middle: "Strategy," mark an $\mathrm{X}$ to indicate what you think about the level of usefulness of the strategy (left column) and another $\mathrm{X}$ to indicate what the implementation of that strategy to read a text in English made you feel (right column). Choose only ONE option in each case.

For example:

\begin{tabular}{cccccccc}
\hline \multicolumn{3}{c}{ I think that the strategy is... } & Strategy & \multicolumn{3}{c}{ Implementing this strategy to gett he gist of a text } \\
made me feel...
\end{tabular}


I think that the strategy is... Strategy Implementing this strategy to gett he gist of a text made me feel...

\begin{tabular}{|c|c|c|c|c|c|c|c|c|}
\hline \multirow[t]{3}{*}{$\begin{array}{l}\text { Very } \\
\text { useful }\end{array}$} & $\begin{array}{c}\text { Use- } \\
\text { ful }\end{array}$ & $\begin{array}{c}\text { A } \\
\text { little } \\
\text { useful }\end{array}$ & Useless & & $\begin{array}{l}\text { Very com- } \\
\text { fortable }\end{array}$ & $\begin{array}{l}\text { Comfort- } \\
\text { able }\end{array}$ & $\begin{array}{c}\text { A little } \\
\text { comfort- } \\
\text { able }\end{array}$ & $\begin{array}{c}\text { Uncomfort- } \\
\text { able }\end{array}$ \\
\hline & & & & $\begin{array}{c}\text { Graphic } \\
\text { organizer }\end{array}$ & & & & \\
\hline & & & & Summary & & & & \\
\hline
\end{tabular}

\section{Appendix 3}

\section{Scales of evaluation for the Graphic Organizers}

\begin{tabular}{cccc}
\hline \multicolumn{4}{c}{ Descriptors for the completion of } \\
\hline Excellent & Good & Below Average & Inefficient \\
3 cells correct & 2 cells correct & 1 cell correct & 0 cells correct \\
\hline
\end{tabular}

\begin{tabular}{cccc}
\hline \multicolumn{4}{c}{ Descriptors for the completion of the diagram in the second and third interventions } \\
\hline Excellent & Good & Below Average & Inefficient \\
$8-7$ cells correct & $6-5$ cells correct & $4-3$ cell correct & $2-0$ cells correct \\
\hline
\end{tabular}

\section{Appendix 4}

\section{Scales of evaluation for the Summary}

Performance Features

Excellent Summary demonstrates a strong focus and concisely catches all the main points of the original article.

The main idea is clearly stated.

The main idea is supported by specific and relevant details.

Details are presented in a logical order.

Ideas are connected to make the writing flow.

All the information provided is supported by the text.

The student accurately translates the text.

Good Restated main idea doesn't differ from the first sentence.

The main idea is mostly supported with specific and relevant details giving the reader adequate understanding of content of original article.

Important details might be missing.

Ideas are in logical order.

The majority of the information provided is supported by the text.

The student shows a few problems of accuracy to translate the text. 
Below Main idea is unclear - not specifically stated in the writing.

Average Supporting details are only minimally supportive; they are vague or overly too general.

The student provides a few ideas that are irrelevant.

The student provides information that is not well-interpreted.

The student shows a lot of problems of accuracy to translate the text.

The student provides some information that is not supported by the text.

Ideas are in a random order and not logical.

Ineffective There is not a clear topic sentence to indicate the main idea of the summary. The summary only contains some details, which are weak. There is not a clear connection between the topic sentence and its supporting details.

Irrelevant information is provided.

The student provides information that shows lack of understanding of the original text.

The student provides information that is not supported by the text.

The student shows a totally weak accuracy to translate the text.

Ideas are not in logical order.

\section{Bibliography:}

http://www.nald.ca/library/learning/flemings/geninfo/general/lbs5/summary.htm http://parks.sandi.net/pages/Lesson\%20Plans/Summary_Rubric.html 
